\title{
Pengaruh profitabilitas, struktur aktiva dan ukuran perusahaan terhadap struktur modal pada perusahaan properti dan real estate yang terdaftar di BEI 2013-2017
}

\author{
${ }^{1 *}$ Ariyanto \\ ${ }^{1}$ Universitas Sarjanawiyata Tamansiswa, Jalan Kusumanegara Yogyakarta 55165 \\ *e-mail korespondensi: ariyantoajah556@gmail.com
}

\begin{tabular}{|c|c|}
\hline Keywords & Abstract \\
\hline $\begin{array}{l}\text { Profitability, Asset } \\
\text { Structure, Company } \\
\text { Size, Debt to Equity } \\
\text { Ratio }\end{array}$ & $\begin{array}{l}\text { The purpose of this study is to describe (1) the effect of profitability, asset structure } \\
\text { and company size on capital structure simultaneously, (2) Effect of profitability on } \\
\text { capital structure, (3) Effect of asset structure towards capital structure, (4) Effect of } \\
\text { firm size on capital structure. This research belongs to the type of correlational } \\
\text { research. The population in this study is the Property and Real Estate Services } \\
\text { Company listed on the Stock Exchange in 2013-2017 which has a total assets of at } \\
\text { least } 10 \text { trillion. To determine the sample, researchers use financial statement data. } \\
\text { The research sample was obtained from financial data found at www.idx.com. The } \\
\text { research population was } 8 \text { companies in } 5 \text { periods. The data analysis technique used } \\
\text { is the classic assumption test, multiple regression test, simultaneous F test, t test and } \\
\text { determination test. }\end{array}$ \\
\hline
\end{tabular}

\begin{abstract}
Profitabilitas, Struktur Aset, Ukuran Perusahaan, Rasio Hutang terhadap Ekuitas

Tujuan penelitian ini adalah untuk mendeskripsikan (1) pengaruh profitabilitas, struktur aset dan ukuran perusahaan terhadap struktur modal secara simultan, (2) Pengaruh profitabilitas terhadap struktur modal, (3) Pengaruh struktur aset terhadap struktur modal, (4) Pengaruh ukuran perusahaan terhadap struktur modal. Penelitian ini termasuk jenis penelitian korelasional. Populasi dalam penelitian ini adalah Perusahaan Jasa Properti dan Real Estate yang terdaftar di BEI tahun 2013-2017 yang memiliki total aset minimal 10 triliun. Untuk menentukan sampel peneliti menggunakan data laporan keuangan. Sampel penelitian diperoleh dari data keuangan yang terdapat di www.idx.com. Populasi penelitian adalah 8 perusahaan dalam 5 periode. Teknik analisis data yang digunakan adalah uji asumsi klasik, uji regresi berganda, uji F simultan, uji t dan uji determinasi.
\end{abstract}

\section{PENDAHULUAN}

Sebuah perusahaan selalu membutuhkan modal baik untuk pembukaan bisnis maupun dalam pengembangan bisnisnya. Masalah pendanaan tidak akan lepas dari sebuah perusahaan yang meliputi seberapa besar kemampuan perusahaan dalam memenuhi kebutuhan dana yang akan digunakan untuk beroperasi dan mengembangkan usahanya. Pemenuhan modal usaha dapat dilakukan dengan pendanaan internal maupun eksternal. 
Brigham (2011) menyatakan bahwa perusahaan yang sedang berkembang membutuhkan modal yang berasal dari utang maupun ekuitas. Perusahaan harus memahami komponenkomponen utama struktur modal (Keown, 2010). Struktur modal yang optimal adalah struktur modal perusahaan yang akan memaksimalkan harga sahamnya. Terlalu banyak utang akan dapat menghambat perkembangan perusahaan yang juga akan membuat pemegang saham berpikir dua kali untuk tetap menanamkan modalnya

Sesuai dengan perkembangan jaman dimulai dengan perkembangan ilmu pengetahuan dan teknologi yang semakin hari semakin pesat diikuti oleh peningkatan pembangunanpembangunan negara berkembang di wilayah Asia yang semakin maju. Hal ini menuntut negara Indonesia untuk mengimbangi agar tidak tertinggal dengan negara-negara lainya khususnya pembangunan infrastruktur, karena dengan pembangunan daerah melalui perbaikan pembangunan infrastruktur akan mencerminkan keadaan negara Indonesia sendiri.

Pembangunan infrastruktur akan banyak memicu kemajuan pada sektor perekonomian. Dalam proses peningkatan pembangunan akan menimbulkan banyaknya perusahaan di bidang properti dan real estate, sehingga akan muncul pengusaha-pengusaha baru dibidang jasa tersebut. Perusahaan properti dan real estate juga berperan penting dalam pemasukan negara dalam bentuk pajak. Di Indonesia saat ini terdapat banyak perusahaan properti dan real estate yang Go public.

Peluang pembangunan yang terus meningkat di berbagai wilayah dengan didukung jumlah penduduk Indonesia yang begitu banyak dengan kebiasaan masyarakat yang berpola hidup konsumtif tentu membuat para investor mulai melirik berinvestasi pada sektor ini. Sektor properti biasanya juga dipilih para investor untuk berinvestasi jangka panjang karena usaha pada sektor ini merupakan aktiva multiguna yang dapat digunakan oleh suatu perusahaan sebagai jaminan, oleh karena itu perusahaan properti dan real estate mempunyai risiko yang tinggi. Sesuai pada artikel : "Indonesia misalnya, pertumbuhan di sektor properti terus didorong oleh pesatnya pertumbuhan masyarakat kelas menengah, yang pada tahun 2013 telah meningkat 37 persen dari tahun 2004 menjadi sebesar 56,7 persen meski aktivitasnya sempat menurun kareuna segala isu politik dan ekonomi lainnya, jumlah populasi yang besar ini tidak mungkin dilewatkan para investor sebagai peluang yang menguntungkan" (sumber: http://www./lamudi.co.id/journal/2014-satu-tahun-di-batas-realestate/ )

Dengan adanya pengembangan perusahaan di sektor properti dan real estate dalam kiprahnya sebagai pendorong pembangunan suatu Negara sehingga memunculkan peluang besar bagi para investor maka penulis tertarik untuk melakukan penelitian dengan judul "Pengaruh Profitabilitas, Struktur Aktiva dan Ukuran Perusahaan terhadap Strukur Modal pada Perusahaan properti dan real estate yang terdaftar di bursa efek indonesia (BEI) periode 2013-2017'. 


\section{KAJIAN LITARATUR DAN PENGEMBANGAN HIPOTESIS}

\section{Struktur Modal}

Menurut Horne (2005) struktur modal adalah bauran atau proporsi pendanaan permanen jangka panjang perusahaan yang diwakili oleh utang, saham preferen dan ekuitas saham biasa. Hal ini menunjukkan bahwa struktur modal menganalisis perimbangan antara total hutang jangka panjang dengan modal sendiri. Dengan demikian struktur modal ditentukan oleh perbandingan antara hutang jangka panjang dan modal sendiri yang digunakan oleh perusahaan. Menurut Brigham (2011) struktur modal yang optimal merupakan struktur modal yang akan memaksimalkan harga saham perusahaan, dan struktur ini pada umumnya meminta rasio utang yang lebih rendah daripada rasio yang memaksimalkan EPS yang diharapkan. Penentuan struktur modal akan melibatkan pertukaran antara risiko dan pengembalian.

Menggunakan utang dengan jumlah yang lebih besar akan meningkatkan risiko yang ditanggung oleh pemegang saham. Namun, menggunakan lebih banyak utang pada umumnya akan meningkatkan perkiraan pengembalian atas ekuitas. Risiko yang semakin tinggi terkait dengan utang yang jumlahnya lebih besar cenderung akan menurunkan harga saham, tetapi perkiraan tingkat pengembalian yang lebih tinggi diakibatkan oleh utang yang lebih besar akan menaikkan harga saham tersebut. Perusahaan akan berusaha untuk mencari struktur modal yang menghasilkan keseimbangan antara risiko dan pengembalian yang akan memaksimalkan harga saham. Ada beberapa pandangan mengenai teori yang berhubungan dengan struktur modal. Beberapa teori yang berkaitan dengan keputusan struktur modal antara lain:

1) Pecking Order Theory; dikemukakan oleh Majluf pada tahun 1984 ( dalam Agus ,2011). Teori ini menyatakan bahwa perusahaan cenderung menggunakan sumber pendanaan internal terlebih dahulu yaitu dari laba yang ditahan yang dihasilkan dari kegiatan operasional perusahaan, jika pendanaan eksternal diperlukan, maka perusahaan akan memilih pertama kali mulai dari sekuritas yang paling aman lalu turun ke yang lebih berisiko.

2) Agency Theory; Dalam Agency Theory menyarankan bahwa optimal capital dan ownership structures dapat digunakan untuk hmengurangi biaya agensi. Biaya agensi atau biaya keagenan adalah biaya yang timbul karena perusahaan menggunakan hutang dan melibatkan hubungan antara pemilik perusahaan (pemegang saham) dan kreditur. Biaya keagenan ini muncul dari problem keagenan atau agency problem. Jika perusahaan menggunakan hutang ada kemungkinan pemilik perusahaan melakukan tindakan yang merugikan kreditur, misalnya perusahaan melakukan investasi pada proyek-proyek yang berisiko tinggi (Atmaja, 2008).

3) Trade-Off Theory; Dalam trade off theory perusahaan menukarkan keuntungankeuntungan pendanaan melalui hutang dengan tingkat suku bunga dan biaya kebangkrutan yang lebih tinggi. Dalam trade off theory memberikan tiga masukan yang penting: i) perusahaan yang memiliki aktiva yang tinggi variabilitas keuntungannya akan memiliki probabilitas financial distress yang besar, perusahaan yang seperti ini harus menggunakan sedikit hutang, ii) aktiva tetap yang khas, aktiva yang tidak nampak 
dan kesempatan bertumbuh akan kehilangan banyak nilai jika terjadi financial distress. Perusahaan yang menggunakan aktiva semacam ini seharusnya menggunakan sedikit hutang, iii) perusahaan yang membayar pajak yang tinggi sebaiknya lebih banyak menggunakan hutang dibanding perusahaan yang membayar pajak yang rendah (Atmaja, 2008)

Menurut Sjahrial (2013) strukttur modal dapat diukur dengan rasio Rasio Total Utang Terhadap Modal (Total Debt to Equity Ratio/DER). Rasio ini digunakan untuk mengukur perimbangan antara kewajiban yang dimiliki perusahaan dengan modal sendiri. Rasio ini juga dapat berarti sebagai kemampuan perusahaan dalam memenuhi kewajiban membayar utangnya dengan jaminan modal sendiri.

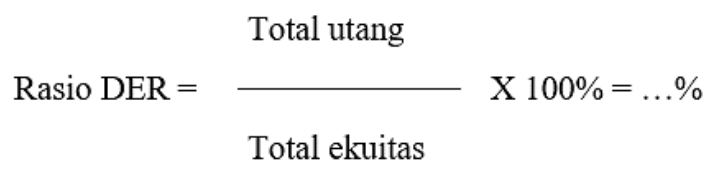

\section{Profitabilitas (ROA)}

Menurut Sartono (dalam Sri Hermuningsih, 2012) Profitabilitas adalah kemampuan perusahaan memperoleh laba. Profitabilitas periode sebelumnya merupakan faktor penting dalam menentukan struktur modal. Perusahaan dengan profitabilitas yang tinggi akan memiliki dana internal (laba) yang lebih banyak dari pada perusahaan dengan profitabilitas rendah. Dengan laba yang besar, perusahaan akan lebih senang menggunakan laba ditahan sebelum menggunakan hutang. Tingkat profitabilitas dapat menunjukkan kemampuan perusahaan untuk mendanai kegiatan operasionalnya sendiri. Menurut Brigham (2011) Profitabilitas adalah hasil bersih dari serangkaian kebijakan dan keputusan. Profitabilitas menggambarkan tingkat keuntungan yang diperoleh perusahaan dalam periode tertentu. Profitabilitas dapat dinilai dengan berbagai cara, salah satunya adalah menggunakan rasio. Rasio Profitabilitas. Return on Assets mengukur kemampuan perusahaan dalam memanfaatkan aktivanya untuk memperoleh laba. Ratio ini mengukur tingkat kembalian investasi yang telah dilakukan oleh perusahaan dengan menggunakan seluruh dana (aktiva) yang dimilikinya.

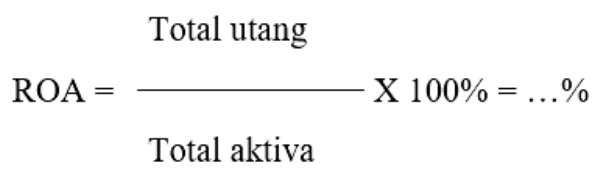

\section{Struktur Aktiva}

Menurut Brigham (2006). Struktur Aktiva adalah perimbangan atau perbandingan antara aktiva tetap dengan total aktiva, perusahaan yang asetnya memadai atau aktivanya memiliki perbandingan aktiva tetap jangka panjang lebih besar akan menggunakan hutang jangka panjang lebih banyak karena aktiva tetap yang ada dapat digunakan sebagai jaminan hutang. Maka dapat dikatakan struktur aktiva dapat digunakan untuk menentukan seberapa besar hutang jangka panjang yang dapat diambil dan hal ini akan berpengaruh terhadap 
penentuan besarnya struktur modal. Dalam Penelitian ini, struktur aktiva dapat dihitung dengan rumus:

$$
\text { Struktut aktiva }=\frac{\text { Aktiva tetap }}{\text { Total aktiva }} \times 100 \%=\ldots \%
$$

\section{Ukuran Perusahaan}

Menurut Sujianto (2001), ukuran perusahaan menggambarkan besar kecilnya suatu perusahaan yang ditunjukkan oleh total aktiva jumlah penjualan, rata-rata total penjualan asset, dan rata-rata total aktiva. Dalam penelitian ini ukuran perusahaan diukur melalui total asset yang diproksikan dengan nilai logaritma natural dari total asset perusahaan (Ln Total Asset). Menurut Seftianne (2011), ukuran perusahaan memiliki pengaruh terhadap struktur modal perusahaan. Hal ini dikarenakan perusahaan yang berskala besar akan lebih mudah dalam mendapatkan investor yang hendak menanamkan modal dan dalam hal perolehan kredit dibanding perusahaan kecil, maka semakin besar ukuran suatu perusahaan semakin besar pula kesempatan perusahaan tersebut memperoleh pendanaan eksternal. Semakin besar ukuran suatu perusahaan, maka kecenderungan menggunakan modal asing juga semakin besar.

Ukuran perusahaan dapat diukur melalui total asset yang diproksikan dengan nilai logaritma natural dari total asset perusahaan Sujianto (2001).

Ukuran Perusahaan $=$ Ln (total aktiva)

\section{METODE PENELITIAN}

Penelitian yang digunakan adalah penelitian kuantitatif dengan menggunakan pendekatan penelitian korelasional (correlational research). Penelitian korelasional adalah tipe penelitian dengan karakteristik masalah berupa pengaruh antara dua variabel atau lebih dengan tujuan untuk melihat ada atau tidaknya hubungan antara variabel satu dengan variabel lainya. Penelitian ini menguji pengaruh antara variabel bebas yaitu profitabilitas (ROA), struktur aktiva dan ukuran perusahaan dengan variabel terikatnya yaitu struktur modal (DER) pada perusahaan properti dan real estate yang terdaftar di bursa efek Indonesia (BEI) periode 2013-2017.

Populasi adalah wilayah generalisasi yang terdiri atas objek/subjek yang mempunyai kualitas atau karakteristik tertentu yang ditetapkan oleh peneliti untuk dipelajari kemudian ditarik kesimpulan, Sugiyono (2012). Populasi dalam penelitian ini adalah Semua perusahaan properti dan real estate yang terdaftar di Bursa Efek Indonesia periode 20132017 dan memiliki total aset diatas $10 \mathrm{~T}$.

Sampel adalah bagian dari jumlah dan karakteristik yang dimiliki oleh populasi. tersebut Sugiyono (2012). Syarat utama dalam pengambilan sampel suatu populasi adalah sampel harus mewakili populasi dan harus dalam bentuk kecil. Teknik pengambilan sampel yang digunakan dalam penelitian ini adalah menggunakan metode purposive sampling, yaitu pengambilan sampel berdasarkan pertimbangan-pertimbangan tertentu dengan membuat 
kriteria yang harus dipenuhi. Adapun kriteria dalam pengambilan sampel pada penelitian ini adalah sebagai berikut:

a. Perusahaan properti dan real estate yang sudah dan masih terdaftar di Bursa Efek Indonesia periode 2013-2017.

b. Perusahaan properti dan real estate yang menerbitkan laporan keuangan yang berakhir pada tanggal 31 Desember selama periode pengamatan.

c. Perusahaan yang memiliki data keuangan lengkap untuk menghitung variabelvariabel dalam penelitian ini selama periode pengamatan yaitu tahun 2013-2017.

d. Sampel dengan 8 perusahaan properti dan real estate yang memiliki total aset diatas 10 triliun yaitu Agung Podomoro Land Tbk, Alam Sutera Realty Tbk, Sentul City Tbk, Bumi Serpong Damai Tbk, Ciputra Development Tbk, Lippo Karawaci Tbk, Pakuwon Jati Tbk dan Summarecon Agung Tbk.

Jenis data yang digunakan dalam penelitiaan ini adalah data sekunder. Data yang digunakan dalam penelitian ini merupakan data tahunan yaitu dari tahun 2013 - 2017. Data ini merupakan data yang bersumber dari laporan keuangan Perusahan properti dan real estate yang diperoleh dari Indonesian Capital Market Directory (ICMD) tahun 2013 - 2017 serta melalui situs www.idx.co.id.

Pengambilan data dilakukan dengan metode dokumentasi, yaitu suatu cara pengumpulan data yang di peroleh dari laporan keuangan perusahaan.

Model regresi merupakan suatu model matematis yang dapat digunakan untuk mengetahui pola hubungan antara dua variabel atau lebih. Persamaan regresi linier berganda dapat dinyatakan sebagai berikut:

$\mathrm{DER}=\alpha+\beta 1 \mathrm{ROA}+\beta 2 \mathrm{SA}+\beta 3 \mathrm{Size}+\mathrm{e}$

Keterangan :

DER $=$ Debt to Equity Ratio (Struktur Modal)

ROA = Return On Assets (Profitabilitas)

$\mathrm{SA}=$ Struktur Aktiva

Size $=$ Ukuran Perusahaan

$\alpha \quad=$ Konstanta

$\beta 1, \beta 2, \beta 3=$ Koefisien Regresi

$\mathrm{e}=$ Error Term

Tabel 1. Daftar Populasi Penelitian

\begin{tabular}{lll}
\hline No & Kode & Nama Perusahaan \\
\hline $\mathbf{1}$ & APLN & Agung Podomoro Land Tbk \\
\hline $\mathbf{2}$ & ASRI & Alam Sutera Realty Tbk \\
\hline $\mathbf{3}$ & BKSL & Sentul City Tbk \\
\hline $\mathbf{4}$ & BSDE & Bumi Serpong Damai Tbk \\
\hline $\mathbf{5}$ & CTRA & Ciputra Development Tbk \\
\hline $\mathbf{6}$ & LPKR & Lippo Karawaci Tbk \\
\hline $\mathbf{7}$ & PWON & Pakuwon Jati Tbk \\
\hline $\mathbf{8}$ & SMRA & Summarecon Agung Tbk \\
\hline
\end{tabular}




\section{HASIL DAN PEMBAHASAN}

Berdasarkan pengolahan data yang dilakukan terhadap 8 perusahaan sub sektor properti dan real estate pada periode 2013-2017 yang meliputi variabel profitabilitas (ROA), struktur aktiva dan ukuran perusahaan terhadap struktur modal (DER) sebagai berikut:

Hipotesis pertama yang menyatakan profitabilitas (ROA), struktur aktiva dan ukuran perusahaan secara simultan berpengaruh terhadap struktur modal (DER) ditolak. Hal ini dibuktikan dari nilai signifikansi uji $\mathrm{F}$ yaitu $0,190>0,05$. Dengan demikian dapat disimpulkan bahwa profitabilitas (ROA), struktur aktiva dan ukuran perusahaan tidak berpengaruh secara simultan terhadap struktur modal (DER) pada perusahaan properti dan real estate yang terdaftar di Bursa Efek Indonesia periode 2013-2017. Sehingga hipotesis pertama ditolak. Sebab dari 3 variabel independen yang diujikan hanya 1 variabel independen yang berpengaruh secara signifikan disamping itu nilai koefisien determinasi hanya sebesar 4,9\%, artinya hanya 4,9\% variabel DER dapat dijelaskan oleh variabel ROA, SA dan Size, sedangkan sisanya sebesar 95,1\% dijelaskan oleh faktor lainya yang tidak diteliti pada model ini. Hasil penelitian ini sama seperti penelitian Inenta (2018) hasil penelitianya menunjukan bahwa struktur aktiva, profitabilitas (ROA) dan ukuran perusahaan tidak berpengaruh secara simultan terhadap struktur modal (DER).

Hipotesis kedua yang menyatakan profitabilitas (ROA) berpengaruh negatif terhadap struktur modal (DER) ditolak. Berdasarkan hasil uji t diketahui bahwa nilai signifikansi 0,595>0,05 yang berarti bahwa profitabilitas (ROA) berpengaruh negatif terhadap struktur modal (DER) ditolak. Artinya Perusahaan dengan profitabilitas yang tinggi belum tentu menggunakan sumber pendanaan internal dari labanya untuk memenuhi kebutuhan modal perusahaan, karena laba perusahaan bisa jadi akan dibagikan sebagai deviden dan kebutuhan modal didapat dari pinjaman atau modal asing. Hasil penelitian ini sama seperti penelitian liwang (2011) hasil penelitianya menunjukan bahwa profitabilitas (ROA) dan ukuran perusahaan tidak berpengaruh terhadap struktur modal (DER).

Hipotesis ketiga yang menyatakan struktur aktiva berpengaruh positif terhadap struktur modal (DER) diterima. Berdasarkan hasil uji t diketahui bahwa nilai signifikansi uji t 0,040 $<0,05$ yang berarti bahwa struktur aktiva berpengaruh positif terhadap struktur modal(DER) diterima. Artinya perusahaan yang asetnya memadai atau aktivanya memiliki perbandingan aktiva tetap jangka panjang lebih besar akan menggunakan hutang jangka panjang lebih banyak karena aktiva tetap yang ada dapat digunakan sebagai jaminan hutang. Maka dapat dikatakan struktur aktiva dapat digunakan untuk menentukan seberapa besar hutang jangka panjang yang dapat diambil dan hal ini akan berpengaruh terhadap penentuan besarnya hutang (DER) yang ada di struktur modal. Hasil penelitian ini sama seperti penelitian Hadianto (2010) dengan judul pengaruh risiko sistematik, struktur aktiva dan jenis perusahaan terhadap struktur modal emiten sektor perambangan, hasil penelitianya menunjukan bahwa ukuran perusahaan berpengaruh positif terhadap struktur modal (DER).

Hipotesis keempat yang menyatakan ukuran perusahaan berpengaruh positif terhadap struktur modal (DER) ditolak. Berdasarkan hasil uji statistik diketahui bahwa nilai signifikansi uji t 0,422 >0,05 yang berarti bahwa ukuran perusahaan berpengaruh positif terhadap struktur modal(DER) ditolak. Artinya belum tentu perusahaan yang berskala besar 
akan lebih mudah dalam mendapatkan tambahan modal, disamping itu perusahaan tidak selalu menggunakan pendanaan eksternal atau hutang,untuk penambahan modal perusahaan, bisa jadi penambahan modal perusahaan diambil dari laba ditahan atau modal sendiri karena penambahan modal perusahaan tergantung situasi dan kondisi ekonomi serta kebijakan perusahaan. Hasil penelitian ini sama seperti penelitian Liwang (2011) dengan judul analisis factor-faktor yang mempengaruhi struktur modal pada perusahaan perusahaan yang tergabung dalam LQ45 periode 2006-2009 yang menunjukan bahwa ukuran perusahaan tidak berpengaruh terhadap struktur modal (DER).

\section{KESIMPULAN DAN SARAN}

Dari uji F dapat diketahui bahwa nilai signifikansi F sebesar 0,190 > 0,05 maka hipotesis ditolak. Hal ini berarti bahwa tidak terdapat pengaruh secara simultan variabel profitabilitas(ROA), struktur aktiva dan ukuran perusahaan terhadap struktur modal (DER) pada perusahaan properti dan real estate yang terdaftar di Bursa Efek Indonesia periode 2013-2017. Sehingga hipotesis pertama ditolak dan tidak terbukti.

Dari uji t parsial dapat diketahui bahwa nilai signifikansi variabel profitabilitas (ROA) 0,595 > 0,05 yang berarti bahwa profitabilitas (ROA) berpengaruh negatif terhadap struktur modal (DER) ditolak. Hal ini berarti bahwa tidak terdapat pengaruh antara profitabilitas (ROA) terhadap struktur modal (DER) pada perusahaan properti dan real estate yang terdaftar di Bursa Efek Indonesia periode 2013-2017. Sehingga hipotesis kedua ditolak dan tidak terbukti.

Dari uji t parsial dapat diketahui bahwa nilai signifikansi variabel struktur aktiva sebesar $0,040<0,05$ maka hipotesis diterima. Hal ini berarti bahwa terdapat pengaruh positif struktur aktiva terhadap struktur modal (DER) pada perusahaan properti dan real estate yang terdaftar di Bursa Efek Indonesia periode 2013-2017. Sehingga hipotesis ketiga diterima dan terbukti.

Dari uji t parsial dapat diketahui bahwa nilai signifikansi variabel ukuran perusahaan $0,422>0,05$ maka hipotesis ditolak. Hal ini berarti bahwa tidak ada pengaruh antara ukuran perusahaan terhadap struktur modal(DER) pada perusahaan properti dan real estate yang terdaftar di Bursa Efek Indonesia periode 2013-2017. Sehingga hipotesis keempat ditolak dan tidak terbukti.

Berdasarkan hasil penelitian diatas, maka saran yang dapat diberikan adalah sebagai berikut:

1. Bagi Investor; Untuk menentukan struktur modal perusahaan tidak hanya melihat dari besarnya rentabilitas perusahaan, tetapi juga tergantung dari situasi dan kondisi ekonomi serta kebijakan yang diterapkan.

2. Bagi Akademisi; Seperti sudah disinggung diatas, nilai Adjusted R square sebesar 0,049 atau 4,9\%. hal ini bermakna bahwa hanya sebesar 4,9\% variabel struktur modal (DER) yang bisa dijelaskan oleh 3 variabel independen yaitu profitabilitas (ROA), struktur aktiva dan ukuran, sedangkan sisanya 95,1\% dijelaskan oleh variabel lain yang tidak masuk dalam model. Hal ini mengindikasikan perlunya untuk meneliti faktor lain atau rasio lain yang dapat mempengaruhi Struktur modal 
dengan jumlah emiten yang lebih banyak sehingga penarikan kesimpulan dapat dilakukan dengan cepat.

\section{DAFTAR PUSTAKA}

Adiyana, Ida Bagus dan Ardiana. 2014. Pengaruh Ukuran Perusahaan, Risiko Bisnis, Pertumbuhan Aset, Profitabilitas dan Likuiditas pada Struktur Modal. E-Jurnal Akuntansi Universitas Udayana 9.3 (2014): 788-802.

Agus Harjito.2011. "Teori Pecking Order dan Trade-off dalam Analisis Struktur Modal di Bursa Efek Indonesia”. Jurnal Siasat Bisnis. Vol. 15, No.2, Juli 2011.

Ariyanto, T. 2002. "Pengaruh Struktur Kepemilikan terhadap Struktur Modal Perusahaan". Jurnal Manajemen Indonesia. Vol.1, No.1. Universitas Gajah Mada.

Atmaja, Lukas Setia.2008. Manajemen Keuangan. Yogyakarta: ANDI.

Brigham dan Houston. 2006. Dasar-dasar manajemen keuangan. Edisi 10. Jakarta : Salemba Empat.

Brigham Dan Houston. 2011. Dasar-dasar Manajemen Keuangan, Buku 2 Edisi 11. Jakarta : Salemba Empat.

Gendro Wiyono. 2011. Merancang Penelitian Bisnis dengan Alat Analisis SPSS dan SmartPLS. UPP STIM YKPN.

Ghozali, Imam.2009. “Aplikasi Analisis Multivariate”. Semarang : UNDIP

Hadianto, Bram. 2010. Pengaruh Risiko Sistematik, Struktur Aktiva, Profitabilitas, dan Jenis Perusahaan terhadap Struktur Modal Emiten Sektor Pertambangan: Pengujian Hipotesis Static-Trade Off. Jurnal Akuntansi. Vol. 2 No. 1, Mei 2010: 15-39.

Horne, James C. Van, dan Machowicz, John M. 2005. Fundamentals of Financial Management, Prinsip-prinsip Manajemen Keuangan. Buku 1 Edisi 12. Jakarta : Salemba Empat.

Inenta Claurina Dewi. 2018. Pengaruh Profitabilitas, Struktur Aktiva dan Ukuran perusahaan terhadap Struktur Modal pada perusahaan Tekstil dan Garment yang terdaftar di Bursa Efek Indonesia(BEI) periode 2011-2016. UAD

Keown, Arthur J. et .al. 2010. Manajemen Keuangan : Prinsip dan Penerapan Jilid 2. Jakarta: Indeks

Liwang, Florencia Paramitha. 2011. Analisis Faktor-faktor yang Mempengaruhi Struktur Modal pada Perusahaan-perusahaan yang tergabung dalam LQ45 Periode Tahun 20062009. Seminar Nasional Teknologi Informasi \& Komunikasi Terapan 2011.

Nuswandari, Cahyani. 2013. Determinan Struktur Modal dalam Perspektif Pecking Order Theory dan Agency Theory. Dinamika Akuntansi, Keuangan dan Perbankan, Mei 2013, Hal: 92-102

Putri, Meidera Elsa Dwi. 2012. "Pengaruh Profitabilitas, Struktur Aktiva dan Ukuran Perusahaan terhadap Struktur Modal pada Perusahaan Manufaktur Sektor Industri Makanan dan Minuman yang terdaftar di Bursa Efek Indonesia". Jurnal Manajemen. Vol.01, No. 01. Universitas Negeri Padang.

Santoso, Singgih, 2000, Buku Latihan SPSS Statistik Parametrik, Elex Media Computindo Jakarta.

Seftianne dan Ratih Handayani. 2011. Faktor-faktor yang Mempengaruhi Struktur Modal pada Perusahaan Publik Sektor Manufaktur. Jurnal Bisnis dan Akuntansi, 13(1), 3956.

Sjahrial, Dermawan dan Djahotman Purba. 2013. Analisis Laporan Keuangan. Jakarta: Mitra Wacana Media. 
Sri Hermuningsih. 2012. "Pengaruh Profitabilitas, Size Terhadap Nilai Perusahaan Dengan Struktur Modal Sebagai Sebagai Variabel Intervening”. Jurnal Siasat Bisnis. Vol. 16, No.2, Juli 2012.

Sugiyono. 2012 . Metode Penelitian Bisnis (Pendekatan Kuantitatif, Kualitatif dan R\&D). Bandung: Alfabeta.

Sujianto. 2001. Dasar-dasar Manajemen Keuangan. Yogyakarta: BPFE

Wimelda, Linda dan Marlinah, Aan. 2013. Variabel-variabel yang mempengaruhi Struktur Modal pada Perusahaan Publik Sektor Non Keuangan. Media Bisnis, Edisi Khusus November. 